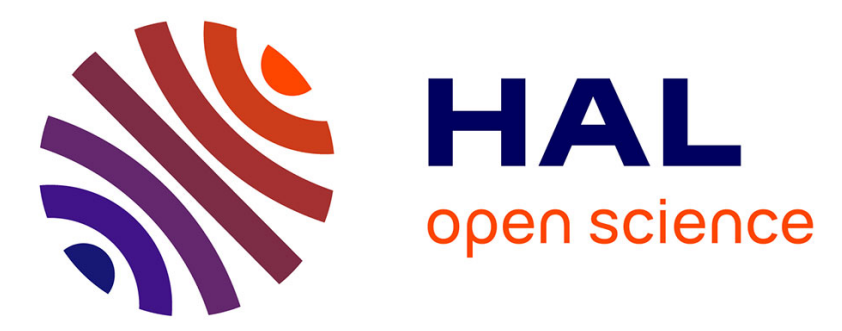

\title{
INTRA-TOURISM TRADE IN EUROPE
}

Jean-Jacques Nowak, Sylvain Petit, Mondher Sahli

\section{To cite this version:}

Jean-Jacques Nowak, Sylvain Petit, Mondher Sahli. INTRA-TOURISM TRADE IN EUROPE.

Tourism Economics, 2012, 18 (6), pp.1287-1311. 10.5367/te.2012.0168 . hal-01831502

\section{HAL Id: hal-01831502 \\ https://hal.science/hal-01831502}

Submitted on 5 Jul 2018

HAL is a multi-disciplinary open access archive for the deposit and dissemination of scientific research documents, whether they are published or not. The documents may come from teaching and research institutions in France or abroad, or from public or private research centers.
L'archive ouverte pluridisciplinaire HAL, est destinée au dépôt et à la diffusion de documents scientifiques de niveau recherche, publiés ou non, émanant des établissements d'enseignement et de recherche français ou étrangers, des laboratoires publics ou privés. 


\title{
INTRA-TOURISM TRADE IN EUROPE
}

\author{
Jean-Jacques Nowak, EQUIPPE, universités de Lille, France
}

Sylvain Petit, IDP, université de Valenciennes and EQUIPPE, France

Mondher Sahli, Victoria University of Wellington, New Zealand

\author{
(Reference: Nowak J-J., Petit S. \& M. Sahli (2013), «Intra-Tourism Trade in Europe», \\ Tourism Economics, 18(6), 1287-1311)
}

\begin{abstract}
In contrast with the stereotypical image of one-way flows going from a few source countries to many host countries, simultaneous exports and imports between two countries appears a plausible phenomenon in tourism. The purpose of this paper is to contribute to our understanding of the empirics of trade in tourism services by studying bilateral intra-tourism trade for a sample of 14 member states of the European Union and by using the most up-to-date and robust method available in the literature to distinguish vertically and horizontally differentiated tourism services: the Azhar and Elliott method (2006). Our results clearly show that a large proportion of European countries simultaneously export and import comparable amounts of tourism services. Moreover, the large predominance of vertical differentiation in these intra-tourism flows suggests that international specialization is taking place in Europe within the tourism sector itself, along the spectrum of quality.
\end{abstract}

Keywords: Bilateral tourism flows, two-way trade, vertical intra-industry, vertical differentiation, services, quality.

JEL: C82, F14, L83.

Address for correspondence: Jean-Jacques Nowak, Laboratoire EQUIPPE, Faculté de sciences économiques et sociales, Université de Lille I, 59655, Villeneuve d'Ascq, France. Email: jean-jacques.nowak@univ-lille1.fr 
Considering the importance of tourism in international trade today, there has been much empirical research devoted last decade to the study of international flows of tourism services and tourism specialization (Peterson, 1988; Sahli, 1999, 2006; Jensen and Zhang, 2006; Algieri, 2006; Webster et al, 2007; Du Toit et al, 2010; Petit, 2010). All of the studies agree on the existence of a pattern of international specialization in tourism, with some countries specialized as exporters of tourism services and others as importers of tourism services. Together with official reports from international organizations (UNWTO, WTO) and studies in tourism geography (Burton, 1994; Williams, 2009), they contribute to give the impression that international tourism trade mainly consists of one-way flows going from a few (rich) source countries to many (less rich) host countries specialized in tourism. This pattern of international flows, asserted for example by Vu and Turner (2006), is supposed to be reflected in large imbalances in tourism trade, with the former accumulating high deficits and the latter high surpluses.

However, two simple observations cast doubt on this picture. Firstly, most exports and imports of international tourism services are made within the same group of rich or emerging countries ${ }^{\mathrm{i}}$, with many countries simultaneously ranking in both the top exporter and the top importer lists such as the United States, France, Germany, United Kingdom, Italy, etc. (UNWTO, 2010a, 2010b). Secondly, the large majority of international flows take place within the tourist's own region, with about four out of five worldwide arrivals originating from the same region (UNWTO, 2010a). Of course, these two characteristics do not mean that tourism flows are necessarily balanced between countries of the same region, but suggest at least that tourism flows might not be as imbalanced as it is often thought. In contrast with the stereotypical image of a one-way flow, two-way trade appears a plausible phenomenon in tourism, especially if trade is considered at a more disaggregated geographic level and if tourism is viewed as an intrinsically differentiated product. The empirical literature has two serious drawbacks: it has been conducted at a high level of geographic aggregation ${ }^{\mathrm{ii}}$ and it considers tourism as a homogenous product. Many factors, however, are responsible for differentiation in tourism, both horizontal (from the point of view of attributes) and vertical (from the point of view of quality). Firstly, geographic location can be viewed as a factor of inherited horizontal differentiation. As long as location is associated with specific inherited natural and cultural/historical endowments, two different destinations should necessarily be considered as different tourism products with distinct attributes (Eilat and Einav, 2004; Cracolici and Nijkamp, 2008). This increases the probability of two-way trade in international tourism services. Note that, by creating tourism resources (not necessarily related to location, i.e. special events, a large range of available activities, entertainment, shopping), governments can actually amplify this kind of differentiation.

Secondly, vertical differentiation could be even more important in tourism than horizontal differentiation, as empirical work has stressed the strategic role of quality and innovation in a given tourism destination's attractiveness. For example, Fick and Ritchie (1991) show that the success of a tourism destination depends critically on the quality of the services it provides. Kalpe and Andvik (2002) demonstrate that quality has positive effects on the economic performance of hotels. Cracolici and Nijkamp (2008) reveal the dominating weight of some qualitative attributes in the evaluation process of tourists in Southern Italian regions. All these aspects have been stressed for a long time by the literature on the destination lifecycle model (Butler, 1980), which predicts that non-differentiated mass destinations end up reaching "maturity" or saturation, followed by decline. Improvements in product quality and innovations are presented as the only means to avoid such a decline by allowing for a rejuvenation of a destination. 
To sum up, many factors constitute grounds for expecting a more complex picture of trade in international tourism than suggested by the existing empirical work, with a significant probability of two-way trade, both horizontal and vertical. The discovery of simultaneous exports and imports within industries (defined as intra-industry trade, IIT) between countries of similar levels of development is one of the most important empirical findings in the field of international trade since the 1960s. Following the pioneering works of Verdoon (1960), Drèze (1961), Balassa (1966) and Grubel (1967) on West-European countries, a considerable number of studies have confirmed the predominance of IIT in high-income and middle-income countries' trade in goods and found IIT to be the most rapidly growing part of post-war trade between developed economies. This empirical finding also led to a renewal of the theory of international trade, because the traditional theory (i.e. based on comparative advantage) was deemed unable to explain trade within industries between similar countries. The seminal articles of Krugman (1979) and Lancaster (1980) laid the foundations of the "new international trade theory", which explains two-way trade in varieties of similar products (horizontal IIT). Twoway trade in products differentiated by quality (vertical IIT) can be modelled using either the traditional framework of comparative advantage (Falvey 1981; Falvey and Kierzkowski 1987; Flam and Helpman 1987) or this "new international trade theory" (Shaked and Sutton 1984).

Most empirical studies on IIT have been confined so far to trade in goods and little attention has been paid to IIT in services. Kierzkowski (1989) was the first to deal with intra-industry trade in services, studying the case of the transportation industry. Tang $(1999,2003)$ conducted an econometric analysis of the determinants of international telephone traffic imbalances between the United States and 148 foreign destinations. Lee and Lloyd (2002) carried out an empirical study for nine service industries on a large sample of countries. Moshirian, Li and Sim (2005), and Webster and Hardwick (2005) studied intra-industry trade in financial services for some OECD countries. In their study of the relevance of international trade theory for tourism, Webster et al. (2007) undertake an empirical evaluation of IIT for international tourism services for a sample of 44 countries using data from the UNWTO. However, they used multilateral data, i.e. for any given country, the different partners it had were grouped together before IIT indices calculations were conducted. This "geographical bias" (Fontagné and Freudenberg 1997) leads to the measurement of a "multilateral" form of intra-industry trade which can overestimate the true value of overlaps in trade. For example, consider a country trading with two partners. This country exports to only one of the two (while not importing from it) and imports only from the other (while not exporting to it). At the bilateral level, this country's trade thus consists of two one-way flows (in opposite directions), one with each partner, which is the opposite of IIT. But considering trade between this country and both of its partners defined as a single trade bloc, and aggregating these two one-way flows would produce a "multilateral" form of intra-industry flows. Consequently, an important part of measured intra-industry trade may be due to an insufficient geographical disaggregation and may appear in this case as a pure artefact. Thus, empirical research on IIT ought to be done on a strict bilateral basis.

The aim of this paper is to contribute to our understanding of the empirics of trade in tourism services by providing a rigorous case study on international tourism trade in the EU-14. Firstly, it is the first empirical investigation that examines trade patterns in services on a strict bilateral basis and at the most detailed level for which bilateral data is available. Our investigation looks at a sample of 14 European countries over the period 2000-2004. Europe is by far the leading regional tourism destination in the world, accounting for 53\% of international tourist arrivals in 2008. The majority of international tourists still travel to and within Europe. 
Together, they made up almost 490 million international tourists in 2008, accounting for 50\% of international tourism receipts (UNWTO 2010b). Europe is also currently the largest source market in the world, generating $55 \%$ of international arrivals, followed by Asia and the Pacific (20\%) and the Americas (16\%) (UNWTO 2010a). The EU-14 has been selected based on considerations of data availability and homogeneity (see section III). It includes the most important source/destination tourism countries in Europe.

Secondly, to the best of our knowledge, our paper is the first to address the issue of vertical and horizontal IIT for tourism. No work on tourism, or even on services, has dealt with the problem of the structure of IIT between two-way trade in horizontally differentiated products and two-way trade in vertically differentiated products. In our paper, after solving the problem of data consistency and elaborating a proxy for export unit values adapted to the case of tourism services, we make an assessment of intra-tourism trade in the EU-14, breaking down horizontal and vertical IIT by using the most up-to-date and robust method available in the literature: the Azhar and Elliott method (2006) ${ }^{\mathrm{iii}}$.

A better understanding of international tourism flows must start with an accurate description of the reality and the characteristics of these flows, especially at the bilateral level. In our opinion, the methodological approach used in this paper is the only way to reach this goal. By measuring the intensity of European bilateral trade in tourism and describing the true pattern of specialization, it provides a more reliable picture of the reality, which is a necessary step for improving tourism demand modeling by means of complementary tools (e.g. gravity models). For example, our conclusions cast doubt on the stereotypical image of one-way flows of international tourists, going from a few source countries to host countries highly specialized in tourism. They show that, in Europe at least, we can no longer consider trade in international tourism services to be of a unidirectional nature - trade in tourism services appears to be less unbalanced than believed. Moreover, the large predominance of vertical differentiation in these intra-tourism flows suggests that international specialization is taking place in Europe within the tourism sector itself, along the spectrum of quality. We claim that, from now on, any assessment of comparative advantage and specialization in tourism should explicitly take into account the dimension of quality.

The paper is structured as follows. Section two describes the empirical method used in this paper to detect and measure intra-industry trade, and to distinguish between its horizontal and vertical components. Section three describes the database and our procedure to deliver a consistent data set for bilateral trade in tourism services. Section four is devoted to the empirical analysis of intra-tourism trade in the EU-14. The paper ends with numerous concluding remarks.

\section{Empirical measure of intra-industry trade}

By analogy with intra-industry trade in manufactured goods, we define intra-tourism trade (ITT) as the situation where two countries trade comparable amounts of international tourism services with each other. Country A exports international tourism services to Country B and, at the same time, imports international tourism services from B. But these two-way flows have to be of comparable magnitude. This definition naturally raises the problem of the choice of an adequate threshold of trade overlap beyond which trade in international 
tourism services can be described as ITT. We will now discuss how these problems have been dealt with in the literature on IIT in goods.

\section{The distinction between inter-industry trade and intra-industry trade}

The most widely used indicator to measure intra-industry trade is Grubel and Lloyd's indicator (1975). The GL indicator calculates the portion of balanced trade (overlap between exports and imports) between two countries, $i$ and $j$, within the total trade of a given industry $k$ :

$$
G L_{i, j}^{k}=\frac{\left[\left(X_{i, j}^{k}+M_{i, j}^{k}\right)-\left|X_{i, j}^{k}-M_{i, j}^{k}\right|\right]}{X_{i, j}^{k}+M_{i, j}^{k}}=1-\frac{\left|X_{i, j}^{k}-M_{i, j}^{k}\right|}{X_{i, j}^{k}+M_{i, j}^{k}}
$$

where $X_{i, j}^{k}$ and $M_{i, j}^{k}$ denote, respectively, exports of $k$ by $i$ to $j$ and imports of $k$ by $i$ from $j$ over one particular year. (Time subscripts are implied.) In this approach, intra-industry trade is thus interpreted as the balanced part of bilateral trade flows.

This indicator falls within the range of 0 to 1 . The higher its value, the larger the share of balanced trade in the total trade of $k$ between the two countries. An index value of 0 indicates exclusive inter-industry trade (good $k$ is only exported or only imported by country $i$ in exchange of a product belonging to a different industry) while an index value of 1 indicates exclusive intra-industry trade in sector $k\left(X_{i, j}^{k}=M_{i, j}^{k}\right)$.

There is no theoretical threshold for the $G L$ indicator beyond which total trade between two countries could be categorically described as being dominated by its intra-industry trade component. However, according to a practice pioneered by Grubel and Lloyd (1975), intra-industry trade is usually said to be dominant in the empirical literature for a GL indicator larger than two-thirds $(G L>66 \%)$. In that case, the minority flow represents at least $50 \%$ of the majority flow.

GL indices can be aggregated across industries (as a trade-weighted average of the industry indices) and/or across partners (as a traded-weighted average of the bilateral indices). Considering the tourism sector only (T), the geographic aggregate GL indicator for country $i$ is computed as follows:

$$
G L_{i \cdot}^{T}=1-\frac{\sum_{j=1}^{N}\left|X_{i, j}^{T}-M_{i, j}^{T}\right|}{\sum_{j=1}^{N}\left(X_{i, j}^{T}+M_{i, j}^{T}\right)}
$$

where $N$ denote the number of country $i$ 's partners.

$G L_{i}^{T}$. describes the share of balanced trade (overlap between exports and imports) between country $i$ and all its $N$ partners in the total trade of tourism services. Despite some shortcomings, the $G L$ index is nowadays the most widely used indicator to assess the extent of intra-industry trade within a sector, especially because it gives results which can be easily interpreted (Helpman, 1981; Vona, 1991; Bernhofen, 1999).

\section{The distinction between horizontal and vertical intra-industry trade}

Three methods have been proposed to disentangle horizontal and vertical intra-industry trade. All three methods rely on the same two basic assumptions regarding prices, unit values and quality of traded products, 
pioneered by Abd-El-Raman (1986a, 1986b). First, it is assumed that differences in prices for an item mirror differences in quality (Stiglitz 1987). Second, average unit values (value/quantity) can reasonably be used as a proxy for prices as prices for traded products are too difficult to gather (there as many prices as transactions, each transaction having its own characteristics: time, place, special conditions...).

The more up-to-date and robust method of disentangling horizontal and vertical intra-industry trade has been put forward by Azhar and Elliott (2006) $)^{\text {iv }}$. Addressing the shortcomings of employing simple unit value ratios to define the boundary between product quality types, these authors proposed a method of measuring and comparing product quality differences based on the traditional $G L$ measure, but applied to the unit value space. There are three steps to this method.

The first step is to characterize each bilateral trade flow as horizontally or vertically differentiated. They define two related indexes of quality differentiation that have symmetrical limits and are projected or scaled equally on both lower and upper bounds. This defines a "product quality space".

The first index of product quality is quite close to Grubel and Lloyd's one and provides a measure of the dispersion of product quality in intra-industry trade flows:

$$
P Q H_{i, j}^{k}=1-\frac{U V_{i, j, k}^{X}-U V_{i, j, k}^{M}}{U V_{i, j, k}^{X}+U V_{i, j, k}^{M}}
$$

with $O<P Q H_{i, j}^{k}<2^{\mathrm{v}} . U V_{i, j, k}$ is the unit value of export $X$ or import $M$ in industry $k$. $i$ and $j$ denote, respectively, the declaring country and its partner. (Time subscripts are still implied.)

The second index provides a measure of vertically differentiated quality dispersion in total intra-industry trade flows:

$$
P Q V_{i, j}^{k}=1+\frac{U V_{i, j, k}^{X}-U V_{i, j, k}^{M}}{U V_{i, j, k}^{X}+U V_{i, j, k}^{M}}
$$

with $0<P Q V_{i, j}^{k}<2$. When all two-way trade flows are equal in quality (no vertical IIT), $P Q V$ is equal to unity. Note that $P Q H_{i, j}^{k}+P Q V_{i, j}^{k}=2$, which leads to $P Q V_{i, j}^{k}=2-P Q H_{i, j}^{k}$. To classify intra-industry trade as horizontally or vertically differentiated, the authors choose an arbitrary cut-off point of ${ }_{-}^{+} 0.15$ ("the $85 \%$ cost share rule"). If $0.85 \leq P Q V_{i, j}^{k}\left(\right.$ or $\left.P Q H_{i, j}^{k}\right) \leq 1.15$, then trade flows between countries $i$ and $j$ for product $k$ are considered to be of similar quality (horizontal differentiation). In other words, imports and exports of a product can be considered as horizontally differentiated two-way trade if they share at least $85 \%$ of their costs (reflected in the price per unit of output).

Otherwise they are supposed to be vertically differentiated. In this case, more precisely, intra-industry trade is classified as high quality if $P Q V_{i, j}^{k}>1.15$ (or $P Q H_{i, j}^{k}<0.85$ ) and low quality if $P Q V_{i, j}^{k}<0.85$ (or $P Q H_{i, j}^{k}>1.15$ ).

The second step is to divide the bilateral flows of country $i$ in two groups according to the nature of product differentiation, as defined in the previous step. The first group $\left(N_{i H}\right)$ contains all horizontally differentiated bilateral flows, the second group $\left(N_{i V}\right)$ all vertically differentiated bilateral flows (with $N_{i H}+N_{i V}=N$, $N$ denoting the number of country $i$ 's partners). The third step is to calculate the intra-industry trade's (i.e. trade 
overlap) share of each category of differentiated products in country $i$ 's total trade (i.e. with all its $N$ partners) of good $k$. These shares are given by the following indicator:

$$
I I T_{i \bullet}^{k} \lambda=\frac{\sum_{j=1}^{N_{i \lambda}}\left(X_{i, j}^{k, \lambda}+M_{i, j}^{k, \lambda}\right)-\sum_{j=1}^{N_{i \lambda}}\left|X_{i, j}^{k, \lambda}-M_{i, j}^{k, \lambda}\right|}{\sum_{j=1}^{N}\left(X_{i, j}^{k}+M_{i, j}^{k}\right)}
$$

where $\lambda$ denotes the category of product differentiation: $H$ for horizontal differentiation, $V$ for vertical differentiation. The numerator gives the value of balanced trade for the category of product differentiation $\lambda$, whereas the denominator gives us the total trade (i.e. with all partners). These two shares sum up to the geographic-aggregate $G L$ indicator as previously defined in (2): $I I T_{i \bullet}^{k} H+I I T_{i \bullet}^{k} V=G L_{i}^{k}$.

Azhar and Elliot's method thus leads to a splitting up of the global trade overlap into overlap in similar products and overlap in vertically differentiated products:

$\frac{\text { balanced trade in } \mathrm{H}}{\text { total trade }(\text { in } \mathrm{H} \text { and } \mathrm{V})}+\frac{\text { balanced trade in } \mathrm{V}}{\text { total trade }(\text { in } \mathrm{H} \text { and } \mathrm{V})}=\frac{\text { total balanced trade }}{\text { total trade }(\text { in } \mathrm{H} \text { and } \mathrm{V})}$.

\section{Data sources and methodology}

\section{Data presentation}

The data used in this work is from reports of tourism services exports and imports, reported on a bilateral basis, i.e. divided by partner country, compiled by the $\operatorname{OECD}(2003,2007)$ from several countries' trade statistics and from Eurostat. Our study covers the period 2000-2004. Among the 24 OECD nations initially encompassed by the database, only the EU-15 countries have been retained ${ }^{\text {vi }}$. These are the only ones (along with Canada) to have reported data for which it is possible to calculate export unit values (a definition of export unit value adapted to tourism services is provided below). However, even with these countries, three problems with the reported statistics remain. Countries such as Denmark and Spain provide bilateral data in international tourism services only with countries that are not part of the European Union. Others reported data on tourism service exports and imports only for certain years: Sweden (2001-2004), Belgium-Luxembourg (2002 and 2003), the Netherlands (no data for 2003). Finally, Germany did not declare its tourism service exports and imports with Finland and Sweden.

Given that certain countries did not declare their bilateral trade in international tourism services, we have two types of bilateral data. In the first case, which is the simplest to deal with, only one of a pair of countries reports its flow with the other country. This type of data has only one source, we will thus refer to them as "non-mirrored data". This data has been maintained in its original state. In this case we rely exclusively on the import and export reports from the single source. ${ }^{\text {vii }}$

The second case is more complex as it concerns the pairs where each country reported its international tourism services flows with the other. For the same flow, there are thus two different sources. We will call this data "mirrored data". The difficulty is that, in general, the importer country and the exporter country report different values for the same flow. This problem is also the case for goods, but in services the differences in reporting seem to be larger. ${ }^{\text {viii }}$ 
Harmonization of tourism "mirrored data"

Among the several methods traditionally used for harmonizing mirrored data, we have chosen the method developed by Lejour and Paiva Verheijden (2004). The main advantage of this method over the others is that it corrects the source of the problem. Our preliminary hypothesis is that some countries have a systematic tendency to overestimate or underestimate their import or export reports. The aim of this method is to identify these countries through econometric regressions. We run the following regression:

$$
\ln \left(i m p_{i j}\right)=\alpha+\beta \ln \left(\exp _{j i}\right)+\sum_{r} \gamma_{r} D_{r}^{E}+\sum_{r} \delta_{r} D_{r}^{I}+\varepsilon_{i j}
$$

Reported tourism services imports from country $i$ to country $j$, imp $i j$, is the dependent variable. There are two sets of independent variables: the reported tourism services exports between these countries, $\exp _{j i}$, and dummies for both reporting exporting countries, $D^{E}$, and reporting importing countries, $D^{I}$. $\alpha$ is a constant representing the reference situation and $\beta$ the coefficient for the $\log$ of reported tourism exports. In the ideal case, where both countries report the same values for the same flow, $\beta$ is equal to 1 and the constant is $0 . \gamma$ and $\delta$ are the coefficients of the dummies for the tourism exporting and importing country respectively. If these coefficients are not statistically significant, then the country $r$ does not have a tendency to overestimate or underestimate its tourism exports and imports ${ }^{\mathrm{ix}}$. The results from the econometric regressions are summarized in Table 1. Compared to the reference variable, certain countries systematically overestimate their reported flows. Austria, France, Germany, Italy, the Netherlands, Sweden and the United Kingdom systematically overestimate their imports of international tourism services, and Belgium and Luxembourg, France, Germany, Greece, Italy, the Netherlands, Portugal, and the United Kingdom systematically overestimate their exports.

TABLE 1

Reported trade data by exporting or importing country according to reported trade data reliability

\begin{tabular}{|c|c|c|c|c|c|c|c|}
\hline \multicolumn{8}{|c|}{ Dependent variable: $\ln M j i$} \\
\hline Exporter & Coefficient & $\begin{array}{c}T \text { of } \\
\text { Student }\end{array}$ & $\begin{array}{c}\text { Reliability } \\
\text { Rank }\end{array}$ & Importer & Coefficient & $\begin{array}{c}T \text { of } \\
\text { Student }\end{array}$ & $\begin{array}{c}\text { Reliability } \\
\text { Rank }\end{array}$ \\
\hline Austria & 0.1089 & 1.18 & 5 & Austria & $0.2774 * *$ & 3.04 & 12 \\
\hline $\begin{array}{l}\text { Belgium- } \\
\text { Luxembourg }\end{array}$ & $0.3986 * *$ & 3.46 & 17 & Belgium-Luxembourg & 0.2196 & 1.79 & 7 \\
\hline Finland & Reference & & 1 & Finland & 0.0242 & 0.31 & 4 \\
\hline France & $0.3243 * *$ & 3.08 & 14 & France & $0.2473 *$ & 2.48 & 11 \\
\hline Germany & $0.4826 * *$ & 4.35 & 20 & Germany & $0.5523 * *$ & 4.34 & 22 \\
\hline Greece & $0.3163 * *$ & 3.04 & 13 & Greece & -0.0092 & -0.10 & 3 \\
\hline Italy & $0.2247 *$ & 2.12 & 9 & Italy & $0.3967 * *$ & 4.07 & 18 \\
\hline Netherlands & $0.3389 * *$ & 3.86 & 15 & Netherlands & $0.2334 *$ & 2.29 & 10 \\
\hline Portugal & $0.1625 *$ & 1.98 & 8 & Portugal & Reference & & 2 \\
\hline Sweden & -0.1467 & -1.71 & 6 & Sweden & $0.5008 * *$ & 5.37 & 21 \\
\hline United Kingdom & $0.4377 * *$ & 4.34 & 19 & United Kingdom & $0.3634 * *$ & 3.15 & 16 \\
\hline Constant & 0.1318 & 1.60 & & & & & \\
\hline $\ln X i j$ & $0.8801 * *$ & 37.28 & & & & & \\
\hline$R^{2}$ & $96.54 \%$ & & & & & & \\
\hline
\end{tabular}

** and * indicate that the variable's coefficient is respectively quite significantly different from 0 (the probability of incorrectly rejecting the hypothesis that the coefficient is 0 is less than 1\%) and significantly different from 0 (the probability of incorrectly rejecting the hypothesis that the coefficient is 0 is less than $5 \%$ ).

Source: OECD data $(2003,2007)$, authors' calculations. 
In order to harmonize the mirrored data, we used the data from the country which is higher placed in the ranking (i.e. having the lower number). For example, for the pair France-Italy, we used the reports of exports from France to Italy (rather than the reports of imports to Italy from France) and the reports of exports from Italy to France (rather than the reports of imports to France from Italy).

\section{Definition and calculation of export unit values for tourism}

We have seen in sub-section II.2 that all methods used to disentangle horizontal and vertical intraindustry trade rely on the assumption that differences in quality can reasonably be assessed by differences in prices. Therefore, it is necessary to define a proxy for tourism prices. The best candidate for this role seems to be the tourism services export unit value. However, two problems arise.

1) The first issue is related to the definition of export unit value in the case of tourism services. What unit should be used to define this value? In fact, reasoning only about the export value per tourist leads us to disregard the length of stay and can lead to spurious conclusions ${ }^{\mathrm{x}}$. Therefore, we decided to define tourism export unit value as the average spending per day of a foreign tourist. Specifically, we defined the unit value of tourism exports from country $A$ to country $B$ as the ratio of the tourism export receipts from $A$ to $B$ divided by the number of total nights spent by $B$ 's travellers in country $A^{\text {xi }}$. Tourism service exports (from the more reliable reporting country in the case of mirrored data) have thus been divided by the number of reported nights spent. Some aberrant figures, 32 in total ( $6 \%$ of the initial sample), were detected and removed from the sample. The period studied is from 2000 (the first period available in the UNWTO data) to 2004 (the last period available in the OECD database).

2) The second problem in determining tourism services export unit values comes from differences in price levels between countries. According to the "Penn effect" (Kravis et al, 1978, 1982; Heston and Summers 1996), the wealthier a country is, the higher its price level. The real per capita GDP of low-income countries relative to that of high-income countries is then greater than is indicated by comparisons based on exchange rate conversions of GDPs into a common currency. The most commonly presented explanation of this phenomenon is the Balassa (1964) - Samuelson (1964) mechanism, based on the differences in productivity between the countries' traded sectors. As the value of tourism exports is strongly dependent on the cost of living, this productivity differential between traded sectors in the two countries risks resulting in a difference in their tourism export unit values even if their tourism services are of identical quality. A higher price in tourism would thus not necessarily be a reflection of superior quality, but of higher productivity in non tourism-related traded sectors. To neutralize this effect of the difference in cost of living, we have deflated the export unit values by the purchasing power parity index (PPP) of CHELEM database (CEPII).

To sum up, country $i$ 's unit value of international tourism services exported to country $j$ has been calculated in the following manner. The total value of international tourism services exported to $j$ has been divided by the number of nights spent in $i$ by foreign tourists from $j$. The result is then divided by the PPP index of the host country $i$ (with France taken as the reference country). One country (Ireland) has been excluded from our analysis because of lack of data with regard to overnight stays. 


\section{Results}

\section{The importance of two-way trade in European tourism flows}

To assess the importance of intra-tourism flows in the EU-14, we first calculated the Grubel and Lloyd indexes for each country in the sample for the period studied (2000-04). With an index contained between 58\% and $60 \%$ on average, this first result shows that two-way tourism trade is of considerable importance in the EU14. If we consider, as is customary in the empirical literature, that intra-industry trade is predominant if the Grubel and Lloyd indicator is higher than $66 \%$, then almost one out of two country pairs (44\%) has tourism trade which is predominantly intra-industry tourism.

The importance of intra-tourism trade is also apparent when considering the distribution of these indexes (pooling 2000-2004; see Graph A in the appendix). This distribution, of a distinctly dissymmetrical shape, clearly indicates the existence of a large proportion of country pairs which are characterized by a very high level of intra-tourism trade: more than a third (35\%) of pairs studied has an index higher than $80 \%$. Conversely, only a small fraction of pairs have highly imbalanced tourism trade: less than $9.5 \%$ of pairs studied have an index below 20\%. It thus seems that in EU-14 tourism trade, a relative symmetry at the bilateral level is much more common than a pronounced dissymmetry. On the whole, our examination shows the reciprocity of tourism trade between two countries to be a phenomenon of great significance in the EU-14.

Tables 2 and 3 indicate, respectively, which pairs of countries have the lowest share of intra-tourism trade and which have the highest. Note that the reported results are in accordance with the distribution of GL indexes and confirm the importance of intra-tourism trade. While all of the 20 pairs of countries displaying the largest shares of intra-tourism trade have an GL indicator larger than $80 \%$, only 9 out the 20 pairs of countries displaying the lowest shares of intra-tourism trade have an indicator lower than $20 \%$. Moreover, these tables suggest some explanations for intra-tourism trade intensity. Cultural and geographic proximity seems to be an important determinant. For example, countries which are quite close geographically (common border) and culturally (common history) like Finland/Sweden, France/Italy, Germany/Denmark or Spain/Portugal are characterized by a high intensity of intra-tourism trade. Conversely, countries which are more distant from a geographic or cultural point of view, like Greece/Ireland, Germany/Spain and Greece/Sweden, are characterized by a small intensity of intra-industry tourism trade. 
TABLE 2

Country pairs displaying the lowest shares of intra-tourism trade (in \%, average of annual indicators, 2000-04)

\begin{tabular}{lll}
\hline Country 1 & Country 2 & GL's index \\
\hline Greece & Ireland & 4.2 \\
Germany & Spain & 15.4 \\
Greece & Sweden & 15.9 \\
Germany & Greece & 16.5 \\
Finland & Greece & 16.7 \\
Spain & United Kingdom & 17.6 \\
Belgium-Luxembourg & Greece & 18.1 \\
Netherlands & Greece & 18.3 \\
Denmark & Greece & 19.2 \\
Austria & Greece & 20.1 \\
Belgium-Luxembourg & Spain & 20.4 \\
Portugal & Sweden & 22.6 \\
Spain & Sweden & 24.5 \\
Ireland & Portugal & 25.6 \\
Portugal & United Kingdom & 28.2 \\
Finland & Portugal & 28.3 \\
Netherlands & Spain & 28.5 \\
France & Netherlands & 28.9 \\
Finland & Spain & 29.5 \\
Greece & United Kingdom & 30.0 \\
\hline
\end{tabular}

Source: OECD (2003, 2007); authors' calculations

TABLE 3

Country pairs displaying the largest shares of intra-tourism trade (in \%, average of annual indicators, 2000-04)

\begin{tabular}{lll}
\hline Country 1 & Country 2 & GL's index \\
\hline Germany & Finland & 97.9 \\
Germany & Sweden & 97.3 \\
Finland & United Kingdom & 96.8 \\
Germany & Netherlands & 94.3 \\
Finland & Sweden & 93.4 \\
United Kingdom & Sweden & 93.1 \\
Germany & Denmark & 92.9 \\
Portugal & Spain & 92.6 \\
France & Italy & 92.5 \\
Denmark & Netherlands & 91.7 \\
Belgium-Luxembourg & Denmark & 91.1 \\
Germany & United Kingdom & 89.9 \\
Austria & France & 89.5 \\
Netherlands & Sweden & 88.5 \\
Belgium-Luxembourg & United Kingdom & 86.9 \\
Netherlands & United Kingdom & 86.4 \\
France & Ireland & 86.3 \\
Ireland & Italy & 86.2 \\
Greece & Portugal & 83.4 \\
Denmark & Finland & 83.1 \\
\hline Source: OECD
\end{tabular}

Source: OECD (2003, 2007); authors' calculations

The second part of this section is devoted to the importance of intra-tourism trade for each country of the sample taken individually ${ }^{x i i}$. In other words, the proportion of intra-tourism trade in total intra-European tourism trade for each country is analysed. To determine this, the geographically aggregated Grubel and Lloyd 
indicator (see equation 2 in section II), with an aggregation across its thirteen European partners, is calculated for each country. These indicators are given in table 4 .

TABLE 4

Share of intra-tourism trade for each country of the EU-14 (in \%) (geographically aggregated Grubel and Lloyd indicator)

\begin{tabular}{ccccccc}
\hline & 2000 & 2001 & 2002 & 2003 & 2004 & $\begin{array}{c}\text { Average } \\
(2000-04)\end{array}$ \\
\hline Germany & 49.7 & 50.9 & 51.7 & 51.0 & 55.8 & 51.8 \\
Austria & 53.5 & 53.5 & 54.4 & 58.1 & 69.0 & 57.7 \\
Belgium-Luxembourg & 56.7 & 56.9 & 54.5 & 54.9 & 56.6 & 55.9 \\
Denmark & 79.1 & 79.1 & 75.1 & 61.9 & 64.4 & 71.9 \\
Spain & 30.0 & 30.4 & 32.9 & 32.4 & 34.6 & 32.1 \\
Finland & 76.8 & 78.9 & 77.6 & 80.6 & 79.3 & 78.6 \\
France & 58.0 & 58.9 & 58.6 & 54.6 & 58.3 & 57.7 \\
Greece & 37.4 & 36.9 & 34.2 & 33.8 & 30.7 & 34.6 \\
Italy & 59.3 & 57.5 & 57.7 & 59.1 & 60.7 & 58.9 \\
Netherlands & 74.9 & 73.4 & 75.4 & 62.7 & 65.3 & 70.3 \\
Portugal & 58.3 & 56.8 & 56.6 & 55.6 & 56.0 & 56.7 \\
United Kingdom & 48.5 & 44.3 & 46.4 & 43.7 & 44.3 & 45.4 \\
Sweden & 69.7 & 61.8 & 69.3 & 63.5 & 65.2 & 65.9 \\
\hline
\end{tabular}

Source: OECD (2003, 2007); authors' calculations

The average GL indicators for countries over the entire period range from $30.0 \%$ (Spain) to $80.6 \%$ (Finland). Three groups of countries can be identified.

1) Three countries have only a small share of intra-tourism trade $(G L<50 \%)$ : Spain, Greece, and the United Kingdom. Within the EU-14, these countries either have a pronounced comparative advantage in the tourism industry (Spain and Greece) or a pronounced comparative disadvantage (the United Kingdom) (for further details, see Nowak et al, 2010). These three countries are responsible for $30 \%$ of the tourism exports in our sample. They fit in perfectly with the traditional image of international tourism service trade, with a clear polarization between host countries and source countries.

2) Seven countries, which represent more than half the sample, have a large amount of intra-tourism trade $^{\text {xiii }}$ : Germany, Austria, Belgium-Luxembourg, France, Italy, the Netherlands and Portugal. This group generates nearly $62 \%$ of the EU-14's tourism exports. Note that three of the five biggest exporters of tourism services worldwide belong to this group and are thus characterized by a high proportion of intra-tourism trade.

3) The last three countries have trade in international tourism services that are markedly dominated by intra-industry trade, since their geographic aggregate $G L$ is greater than 66\%: Denmark, Finland and Sweden. All three are located in the North of the EU-14 and their exports of tourism services are limited (they make up only $10 \%$ of the EU-14's exports). For these countries, a relative equilibrium of their tourism balance is the rule.

At the level of the EU-14 as a whole, the aggregated Grubel and Lloyd indicator (trade-weighted average of the previous 13 national GL indicators) adds up to 53\%. This proportion is markedly higher than for the trade of goods, since Brülhart (2008) estimated the weighted intra-EU14 GL indicator for goods to be merely $46.6 \%$ in 2006 . When these indexes are compared to those for manufactured goods, which empirical studies have shown to display high levels of intra-industry trade, international tourism services still rank highly. According to 
the GL indicators by industry calculated for the EU-14 by Fontagné et al, (1997), only the sector "other transport equipment" has a higher rate of intra-industry trade than tourism (approximately 65\% over 1990-94), the following sectors having indicators of circa 45\%: "non electrical machinery", "professional goods", "motor vehicles $^{\mathrm{xiv}}$.

To conclude, this sub-section reveals that intra-tourism trade is not a marginal phenomenon in intraEU14 relationships. Two-way trade in European tourism flows appears to be at least as significant as one-way trade, if not overwhelmingly predominant. In any case, the observed level of intra-industry trade in tourism services seems on average to be much higher than that seen in goods trade. Only a very few countries are characterized by low intra-tourism trade. These results cast doubts on the stereotypical image of one-way flows of international tourists; going from very few source countries to host countries highly specialized in tourism. They show that, in Europe at least, we can no longer consider trade in international tourism services to be of a univocal or unidirectional nature, with a polarization between exclusively host countries on the one hand and exclusively source countries on the other. Given the importance of intra-tourism flows in total intra-EU14 tourism flows, trade in tourism services appears to be less unbalanced than it often believed.

The predominance of tourism trade in quality-differentiated products

This section assesses the proportions of, respectively, trade of horizontally differentiated products and trade of vertically differentiated products within total intra-tourism trade, using Azhar and Elliott's method (2006). Table 5 shows the share of each type of trade in bilateral intra-EU14 tourism trade, by year, for a threshold of 15\% (Azhar and Elliot" "85\% cost share rule")

TABLE 5

Decomposition of bilateral tourism flows in the EU-14 (in \%), according to Azhar and Elliott's method (2006)

\begin{tabular}{cccccc}
\hline & 2000 & 2001 & 2002 & 2003 & 2004 \\
\hline Horizontal intra-tourism trade & 9.7 & 8.2 & 9.5 & 13.3 & 16.30 \\
Vertical intra-tourism trade & 42.7 & 43.5 & 43.2 & 37.4 & 36.2 \\
Inter-industry trade & 47.6 & 48.3 & 47.3 & 49.3 & 47.5 \\
\hline
\end{tabular}

Source: OECD (2003, 2007), UNWTO (2006), CEPII (2006); authors' calculations.

Note: a threshold of $15 \%$ for unit value differences has been used (Azhar and Elliott's " $85 \%$ cost share rule").

Regardless of the year studied, vertical intra-tourism trade always appears as the dominant category in intra-tourism trade. Horizontal intra-tourism trade appears to be very limited, with often less than $10 \%$ of bilateral tourism trade in the EU-14. Intra-tourism trade in Europe is thus essentially composed of trade in international tourism services that are differentiated by their level of quality. Moreover, the distribution between horizontal IIT and vertical IIT appears to be stable over time: the data show that there has been no significant evolution over the period studied. Finally, let us point out that all these results are resistant to major changes to thresholds for unit value differences (see Table $\mathrm{A}$ in the appendix). 
The predominance of vertical intra-tourism trade is confirmed for all EU-14 countries. Table 6 shows, for each country, the geographic aggregated shares of the three types of trade over the four-year period studied. It allows us to more clearly identify countries that exhibit the phenomenon of vertical intra-tourism trade.

TABLE 6

Decomposition of bilateral intra-EU14 tourism flows by country (in \%), according to Azhar and Elliott's (2006) method (2000-2004)

\begin{tabular}{cccc}
\hline & ITTH & ITTV & $\begin{array}{c}\text { Inter-industry } \\
\text { trade }\end{array}$ \\
\hline Germany & 12.2 & 40.4 & 47.4 \\
Austria & 15.4 & 43.1 & 41.5 \\
Belgium-Luxembourg & 24.6 & 32.2 & 43.2 \\
Denmark & 7.5 & 63.9 & 28.6 \\
Spain & 7.5 & 26.2 & 66.3 \\
Finland & 17.7 & 60.5 & 21.8 \\
France & 10.8 & 47.3 & 41.9 \\
Greece & 6.6 & 27.6 & 65.8 \\
Italy & 11.9 & 47.9 & 40.2 \\
Netherlands & 32.2 & 36.5 & 31.3 \\
Portugal & 16.2 & 40.7 & 43.1 \\
United Kingdom & 10.6 & 35.5 & 53.9 \\
Sweden & 9.2 & 57.1 & 33.7 \\
\hline
\end{tabular}

Source: OECD (2003, 2007), UNWTO (2006), CEPII (2006); authors'calculation.

Note: ITTH denotes horizontal intra-tourism trade. ITTV denotes vertical intra-tourism trade.

Table 6 reveals that trade in vertically differentiated products strongly dominates intra-tourism trade in all EU-14 countries. Its share often represents several times the share of trade in horizontally differentiated products, with the noteworthy exception of the Netherlands whose bilateral intra-tourism trade is quite balanced among the three types of flows. The method used in this paper establishes that vertical intra-tourism trade is the most important component of total bilateral tourism trade for 7 countries: Austria, Denmark, Finland, France, Italy, Netherlands and Sweden. However, it should be noted that Netherlands, Belgium-Luxembourg and, to a lesser extent, Finland, Portugal and Austria, hold a significant share of horizontal intra-industry trade.

The importance of intra-tourism flows in European tourism services trade and the large predominance of vertical differentiation in these intra-tourism flows suggest that, in Europe, international specialization is taking place within the tourism sector itself, along ranges of quality of tourism products, rather than between the tourism sector and other sectors. The logic of comparative advantages must probably operate at the level of quality within tourism.

Table 7 provides additional information regarding the nature of quality of vertical intra-tourism trade (ITTV). The focus differs from Table 6 in that we now distinguish between vertical intra-tourism trade of low quality services (LITTV) and vertical intra-tourism trade of high quality services (LITTV) for all EU-14 countries. Recall from Azhar and Elliott's method discussed in section II that, in the case of vertically 
differentiated products, intra-industry trade is classified as high quality if $P Q V_{i, j}^{k}>1.15$ (or $P Q H_{i, j}^{k}<0.85$ ) and as low quality if $P Q V_{i, j}^{k}<0.85$ (or $P Q H_{i, j}^{k}>1.15$ ).

First, three distinct groups of countries can be identified. For the countries of the first group, intra-tourism trade is largely dominated by flows in which the quality of exports is superior to the quality of imports: Germany, Sweden, Belgium-Luxembourg, Italy and Portugal. Even though this group is dominated by Northern European countries, we note the presence of two Southern European countries: the comparison of vertical intratourism trade of low quality services (LITTV) and vertical intra-tourism trade of high quality services (HITTV) shows that Italy and Portugal tend to sell to non-residents tourism services of a higher quality than those purchased abroad by their own residents. Moreover, Table 7 challenges the traditional view of Germany and Sweden when it comes to tourism. These countries are usually considered to be large importers of tourism services only. However, the table shows us that they are major exporters of high quality tourism services: $40.4 \%$ of total German tourism services trade with EU14 is made of exports of higher quality than imports. In Sweden's case, this is in fact the dominant characteristic.

The second group is made up of countries the intra-tourism trade of which is dominated by flows of imports of superior quality to those of exports: Denmark, France, UK and Austria. Here, the most surprising finding is with regard to France whose situation is symmetric to Germany: almost half of its total bilateral tourism flows with the UE14 is made of exports of lower quality than imports. This result may be another symptom of the "French Paradox" (Randriamboarison, 2003): although France has been consistently the world's most popular tourist destinations in terms of tourist arrivals, it generates less tourism receipts than the United States and Spain. International tourists visiting France spend on average less than they do in other countries. Many arguments have been put forward in the literature to explain this paradox. Firstly, due to its geographical position, France is often considered to be a «point of transit » by many international tourists. Secondly, it appears that France endures the disadvantages of «mass tourism»due to tourist saturation (Caccomo and Solonandrasana, 2001).

In the last group of countries, the share of exports of superior quality is not significantly different from the share of imports of superior quality (Spain, Greece and Finland). Note that two of these countries (Spain and Greece) have the lowest rate of vertical intra-tourism trade and total intra-tourism trade of the sample. 
TABLE 7

Decomposition of vertical intra-tourism trade by country (in \%), according to Azhar and Elliott's (2006) method (intra-EU14, 2000-2004)

\begin{tabular}{cccccc}
\hline & ITTH & $\begin{array}{c}\text { ITTV } \\
{[=(1)+(2)]}\end{array}$ & $\begin{array}{c}\text { LITTV } \\
(1)\end{array}$ & $\begin{array}{c}\text { HITTV } \\
(2)\end{array}$ & $\begin{array}{c}\text { Inter- } \\
\text { industry }\end{array}$ \\
\hline Germany & 12.2 & 40.4 & 0.0 & 40.4 & 47,4 \\
Austria & 15.4 & 43.1 & 28.8 & 14.3 & 41.5 \\
Belgium-Luxembourg & 24.6 & 32.2 & 0.1 & 32.1 & 43.2 \\
Denmark & 7.5 & 63.9 & 52.2 & 11.7 & 28.6 \\
Spain & 7.5 & 26.2 & 10.1 & 16.1 & 66.3 \\
Finland & 17.7 & 60.5 & 34.3 & 26.2 & 21.8 \\
France & 10.8 & 47.3 & 47.3 & 0.0 & 41.9 \\
Greece & 6.6 & 27.6 & 13.5 & 14.1 & 65.8 \\
Italy & 11.9 & 47.9 & 1.4 & 29.5 & 40.2 \\
Netherlands & 32.2 & 36.5 & 14.8 & 21.7 & 31.3 \\
Portugal & 16.2 & 40.7 & 7.8 & 32.9 & 43.1 \\
United-Kingdom & 10.6 & 35.5 & 30.5 & 5.0 & 53.9 \\
Sweden & 9.2 & 57.1 & 19.7 & 37.4 & 33.7 \\
\hline
\end{tabular}

Source: OECD (2003, 2007), UNWTO (2006), CEPII (2006); authors'calculation.

Note: ITTH denotes horizontal intra-tourism trade. LITTV denotes vertical intra-tourism trade of low quality services. HITTV denotes vertical intra-tourism trade of high quality services. ITTV denotes total vertical intra-tourism trade (ITTV = LITTV + HITTV).

Finally, these results obtained for vertical intra-tourism trade seem rather different from those obtained for European intra-industry trade patterns of vertically differentiated goods where there is evidence of dividing line between the "North" (up-market goods) and the "South" (medium and down market goods) of Europe (for further details, see Freudenberg and Fontagné, 2002). In the case of tourism, there is no clear polarisation between these two geographical blocs of countries in terms of specialization along ranges of quality.

However, although the above results allow us to better understand the nature and the scale of intratourism trade on a country by country basis, they must be interpreted with some caution because international tourism services are a relatively broad category whose heterogeneity is not really reflected in the aggregated data available. However, this study went the farthest one can go, given the available data on bilateral flows in tourism trade. And even if data should ideally be more disaggregated by tourism products, the fact that the results obtained are so strong suggests that intra-tourism trade, especially of services differentiated by quality, must have some reality.

\section{Conclusion}

The purpose of this paper was to examine intra-tourism trade patterns in a sample of 14 European countries over the period 2000-2004. To the best of our knowledge, this is the first time that this phenomenon is formally analysed on a strict bilateral basis and at the most detailed level for which bilateral data are available. The results presented here are both innovative and quite unexpected.

Firstly, they clearly indicate that a large proportion of European countries simultaneously export and import comparable amounts of tourism services. Consequently, this empirical investigation does not support the 
broad image of international tourism largely dominated by one-way flows, going from a few source countries to host countries highly specialized in tourism. Contrasting with the conclusions of previous studies mentioned in the introduction, our study reveals that the share of two-way trade in European tourism flows is at least as significant as one-way trade. There are only three countries in our sample (Spain, Greece and the United Kingdom) that are characterized by low intra-tourism trade. Furthermore, our results reveal that the observed level of intra-industry trade in tourism services seems on average to be much higher than that seen in goods trade.

Secondly, one of the most important findings of our study is that trade in vertically differentiated tourism products strongly dominates intra-tourism trade. In contrast, the share of intra-industry trade in similar (horizontally differentiated) tourism products appears to be relatively low in our sample of EU-14 countries. This finding suggests that the quality of tourism services plays nowadays an important role in intra-European tourism trade. International specialization is taking place in Europe within the tourism sector itself, along the spectrum of quality. Consequently, the positioning of tourism destinations along the quality ladder can enrich in the future our assessment of comparative advantages in tourism. We claim that quality should be taken into account in any assessment of comparative advantage and specialization in tourism.

Finally, unlike in the case of exports of goods, our empirical investigation of vertically and horizontally differentiated tourism services reveals that there is no substantial different pattern between Northern and Southern European countries. Thus, quality matters in tourism but there is no evidence of geographical dividing line between the two regions.

The high share of intra-tourism trade in Europe found in this paper could well be explained by the common characteristics of the EU countries. Because of history and geography, these countries share many important features (political, social, cultural, religious, etc.) which could be at the root of an important part of their trade. Moreover, since the Schengen agreements, traveling in the intra-Europe area has been simplified for European citizens. However, there are still some differences in the intensity of bilateral flows in tourism services in Europe, which must be related, among other things, to the remaining regulations and barriers, especially in trade in other services inside the EU.

For a better understanding of intra-tourism trade, we suggest as further research to investigate the explaining factors (economic and extra-economic) of the intra-tourism trade intensity in tourism by using econometric regressions. This further research will have to be careful to the tourism industry characteristics and to the quality of available data. The standard technics used for trade in manufactured goods (as logit or logistics regressions) may not be relevant for tourism as the volatility of data is high and the tourism consumption is very particular. This further investigation could open new areas of research to tourism demand modeling. 


\section{Appendix}

GRAPH A

Distribution of the Grubel and Lloyd's indexes for the tourism sector in the EU-14 (2000-2004)

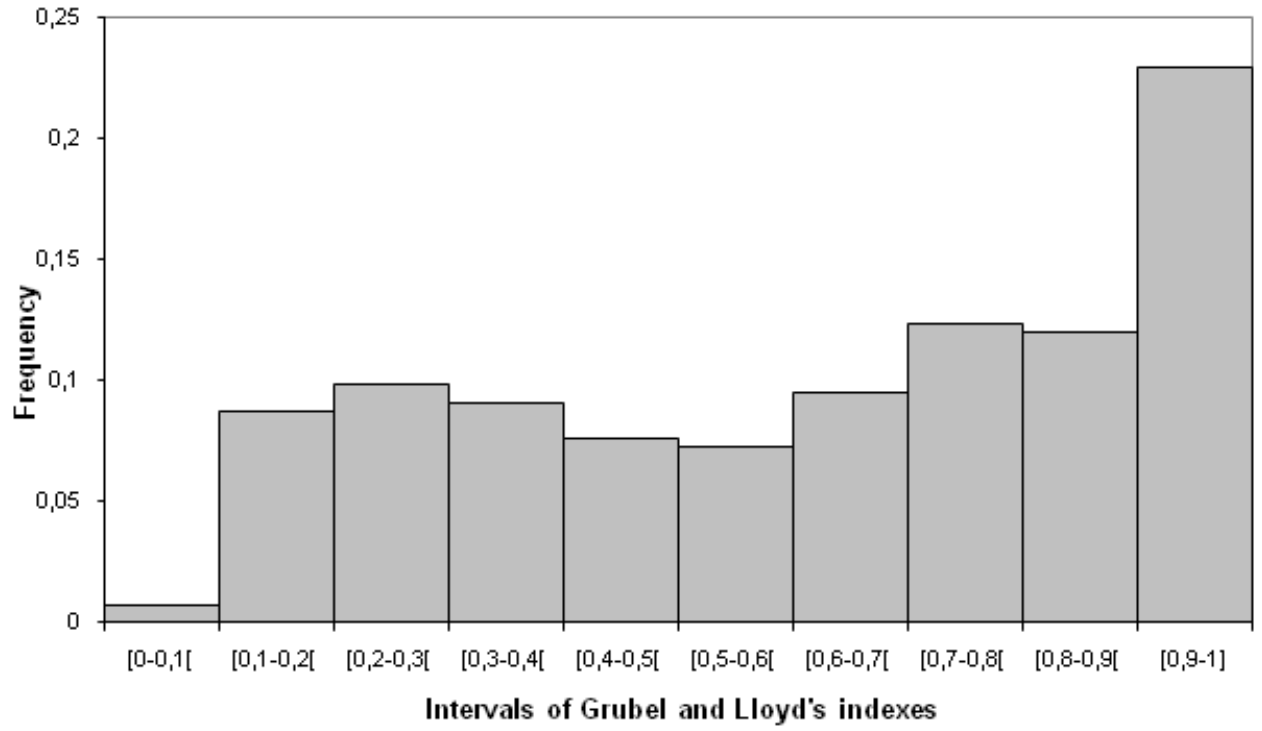

Source: $\operatorname{OECD}(2003,2007)$; authors' calculation

TABLE A

Decomposition of bilateral tourism flows in the EU-14 (in \%), using Azhar and Elliott's method and according to the criterion of similarity applied (2000-2004)

\begin{tabular}{cccccc}
\hline & \multicolumn{5}{c}{ Threshold of quality similarity } \\
\hline & $\leq 0.15$ & $\leq 0.20$ & $\leq 0.25$ & $\leq 0.35$ & $\leq 0.50$ \\
\hline IITH & 11.6 & 14.1 & 18.9 & 25.5 & 30.3 \\
IITV & 41.1 & 38.6 & 33.8 & 27.2 & 22.4 \\
\hline
\end{tabular}

Source: OECD (2003, 2007), UNWTO (2006), CEPII (2006); authors' calculation

Note: if the threshold of similarity is set at 0.35 , the shares of IITH and IITV are $25.5 \%$ and $27.2 \%$.

\section{References}

Abd-El-Rahman, K.S. (1986a), 'La 'différence' et la 'similitude' dans l'analyse de la composition du commerce international', Revue économique, Vol 37, pp 307-339.

Abd-El-Rahman, K.S. (1986b), 'Réexamen de la définition et de la mesure des échanges croisés de produits similaires entre les nations', Revue économique, Vol 37, pp 89-115.

Algieri, B. (2006), 'International tourism specialization of small countries', International Journal of Tourism Research, Vol 8, pp 1-12.

Andressen, M., Harris, R., and Schmitt, N., (2001), Canada-U.S. Intra-Industry Trade Patterns, mimeo, University of Western Ontario. 
Aquino, A. (1978), 'Intra-Industry Trade and Inter-Industry Specialization as Concurrent Sources of International Trade in Manufactures', Weltwirtschaftliches Archiv/ Review of World Economics, Vol 114, pp 275-295.

Azhar, A.K.M., and Elliott, R.J.R. (2006), 'On the Measurement of Product Quality in Intra-Industry Trade', Review of World Economics, Vol 142, pp 476-495.

Azhar, A.K.M., Elliott, R.J.R., and Liu, J. (2008), 'On the Measurement of Product Quality in Intra-Industry Trade: an Empirical Test for China', China Economic Review, Vol 19, pp 336-344.

Balassa, B. (1964), 'The Purchasing Power Parity Doctrine: A Reappraisal', Journal of Political Economy, Vol 72, pp 584-596.

Balassa, B. (1966), 'Tariff Reductions and Trade in Manufactures among Industrial Countries', American Economics Review, Vol 56, pp 466-473.

Bernhofen D.M. (1999), 'Intra-industry trade and strategic interaction: theory and evidence', Journal of International Economics, Vol 47, pp 225-244.

Brülhart, M. (2008), An Account of Global Intra-industry Trade, 1962-2006. Research paper series "Globalisation, Productivity and Technology", n08, The University of Nottingham.

Burton, R. (1994), Geographical patterns of tourism in Europe. In: C. Cooper and A. Lockwood, eds. Progress in tourism, recreation and hospitality, Vol. 5, Chichester: John Wiley and Sons.

Butler, R. (1980), 'The concept of a tourist area cycle of evolution', Canadian Geographer, Vol 24, pp 5-12.

Caccomo J-L. and Solonandrasana B. (2001). L'innovation dans l'industrie touristique, enjeux et stratégies, L'Harmattan.

Centre d'Étude Prospectives et d'Informations Internationales (CEPII) (2006). Comptes harmonisés sur les changes et l'économie mondiale-CHELEM Database [Harmonized Accounts on Trade and World EconomyCHELEM Database].

Cracolici, M-F., and Nijkamp, P. (2008), 'The Attractiveness and Competitiveness of Tourist Destinations : A Study of Southern Italian Regions', Tourism Management, Vol 30, pp 336-344.

Drèze, J. (1961), 'Les exportations intra-CEE en 1958 et la position belge', Recherches Economiques de Louvain, Vol 8, pp 717-738.

Du Toit, L., J. Fourie and D. Trew (2010), The Sources of Comparative Advantages in Tourism. Stellenbosch Economic Working Papers, 01/10, Bureau of Economic Research, University of Stellenbosch.

Eilat, Y. and Einav, L. (2004), 'Determinants of international tourism: a three-dimensional panel data analysis', Applied Economics, Vol 36, pp 1315-1327.

Falvey, R. (1981), 'Commercial Policy and Intra-Industry Trade', Journal of International Economics, Vol 11, pp 495-511.

Falvey, R. and Kierzkowski, H. (1987), 'Product Quality, Intra-Industry Trade and (Im)perfect Competition', in H. Kierzkowski (Ed.), Protection and Competition in International Trade (pp.143-161), Oxford: Basil Blackwell.

Fick, G. and Ritchie, J.R (1991), 'Measuring Services Quality in the Travel and Touristy Industry', Journal of Travel Research, Vol 30, pp 2-9.

Flam, H. and Helpman, E. (1987), 'Vertical Product Differentiation and North-South Trade', American Economic Review, Vol 77, pp 810-822. 
Fontagné, L. and Freudenberg, M. (1997), Intra-Industry Trade: Methodological Issues Reconsidered, CEPII Working Paper, n¹997-02.

Fontagné, L., Freudenberg, M. and Péridy, N. (1997), Trade Patterns Inside the Single Market. CEPR Discussion Paper, Vol. 1959.

Fontagné, L. and Freudenberg, M. (2002), 'Long Term Trends in Intra-Industry Trade',in H-H. Lee \& P.J. Lloyd (Ed.), Frontiers of Research on Intra-industry Trade (pp.131-158), Basingstoke: Palgrave Macmillan.

Fontagné, L., Freudenberg, M., and Gaulier, G. (2005), Disentangling Horizontal and Vertical Intra-Industry Trade. CEPII Working Paper, n²005-10.

Greenaway, D., Hine, C.R. and Milner, C.R. (1995), 'Vertical and Horizontal Intra-Industry Trade: A Cross Country Analysis for the United-Kingdom', Economic Journal, Vol 105, pp 1505-1518.

Grubel, H.G. (1967), 'Intra-Industry Specialization and the Pattern of Trade', Canadian Journal of Economics and Political Science, Vol 33, pp 374-388.

Grubel, H.G. and Lloyd, P.J. (1975), Intra-Industry Trade. The theory and Measurement of International Trade in Differentiated Products, Editions Macmillan Press LTD.

Helpman, E. (1981), 'International Trade in the Presence of Product Differentiation, Economies of Scale and Monopolistic Competition', Journal of International Economics, Vol 11, pp 305-340.

Heston, A. and Summers, R. (1996), 'International price and quantity comparisons: potentials and pitfalls', American Economic Review, Vol 86, pp 20-24.

Jensen, C. and J. Zhang (2006), 'Comparative Advantage Explaining Tourism Flows', Annals of Tourism Research, Vol 34, pp 223-243.

Kalpe, O. and Andvik, K. (2002), 'The Economics of Quality in the Hotel Business', Tourism Economics, Vol 8, pp 361-376.

Kierzkowski, H. (1989), 'Intra-Industry Trade in Transportation Services', in P. K. M. Tharakan \& J. Kol (Ed.), Intra-Industry Trade: Theory, Evidence and Extensions (pp.92-100), London: Macmillan.

Kravis, I. B., Heston, A. and Summers, R. (1978), 'Real GDP per capita for more than one hundred countries' The Economic Journal, Vol 88, pp 215-242.

Kravis I. B., Heston, A. and Summers, R. (1982), World Product and Income: International Comparisons of Real Gross Product. Phase III of the United Nations International Comparison Project, published for the World Bank by The Johns Hopkins University Press, Baltimore and London.

Krugman, P. (1979), 'Increasing Returns, monopolistic competition and international trade', Journal of International Economics, Vol 9, pp 469-479.

Lancaster, K. (1980), 'Intra-Industry Trade under Perfect Monopolistic Competition', Journal of International Economics, Vol 10, pp 151-175.

Lee, H-H., and Lloyd, P.J. (2002), 'Intra-Industry Trade in Services', in H-H. Lee and P.J. Lloyd (Ed.), Frontiers of Research in Intra-Industry Trade (p.159-179), Basingstoke: Palgrave Macmillan.

Lejour, A., and De Paiva Verheijden, J-W. (2004), Services trade within Canada and the European Union. What do they have in common?, CPB Discussion Paper, $n^{\circ} 42$.

Moshirian, F., Li, D., and Sim, A-B. (2005), 'Intra-industry trade in financial services', Journal of International Money and Finance, Vol 24, pp 1090-1107. 
Nowak, J-J., Petit, S., and Sahli, M. (2010), 'Tourism and Globalization: The International Division of Tourism Production', Journal of Travel Research, Vol 49, pp 228-245.

Peterson, J.C. (1988), 'Export shares and revealed comparative advantage: a study of international travel', Applied Economics, Vol 20, pp 351-65.

Petit S. (2011), Une analyse du tourisme international : fragmentation de la production, flux croisés, effets redistributifs, Thèse de doctorat, Université Lille 1 - Sciences et Technologies.

Organization for Economic Co-operation and Development (OECD) (2003, 2007), Sources OECD Services Statistics (Detailed tables by Partner Country).

Randriamboarison, R. (2003), Modélisation et estimation de la demande touristique: Un essai pour l'explication du secteur touristique français, Thèse de doctorat, Université de Perpignan.

Sahli M. (1999), Tourisme et Spécialisation Internationale, Thèse de doctorat, Université Paris I Panthéon Sorbonne.

Sahli M. (2006), 'Tourism Specialization: a comparison of 19 OECD destinations', in International Handbook of Economics of Tourism (pp 705-732), edited by Dwyer L and P. Forsyth. Edwar Elgar Edition.

Samuelson P.A. (1964), 'Theoretical notes on trade problems', Review of Economics and Statistics, Vol 46, pp 145-154.

Shaked, A., and Sutton J. (1984), 'Natural Oligopolies and International Trade', in H. Kierzkowski (Ed.), Monopolistic Competition and International Trade (pp 34-50), London: Claredon.

Stiglitz, J. E. (1987), 'The Causes and Consequences of the Dependence of Quality on Price', Journal of Economic Literature, Vol 25, pp 1-48.

Tang, L. (1999), Intra-Industry Trade in Services: A Case Study of the International Telephone Industry, Mimeo, Drexel University.

Tang, L. (2003), 'The determinants of international telephone traffic imbalances', Information Economics and Policy, Vol 15, pp 127-145.

United Nations World Tourism Organization (UNWTO) (2006), Yearbook of Tourism statistics. Madrid.

United Nations World Tourism Organization (UNWTO) (2010a), Tourism Higlights. Available at http://www.unwto.org/facts/eng/pdf/highlights/UNWTO_Highlights10_en_HR.pdf.

United Nations World Tourism Organization (UNWTO) (2010b), World Tourism Barometer, Vol 8 (3), October, Madrid.

Verdoon, P.J. (1960), 'The Intra-Bloc trade of Benelux', in G. Robinson (Ed.), Economics Consequences of the Size of Nations (pp.291-329), London: Macmillan Press.

Vona S. (1991), 'On the Measurement of Intra-Industry Trade: Some Further Thoughts', Weltwirtschaftliches Archiv/Review of World Economics, Vol 127, pp 678-700.

Vu, C.J. and Turner, L. (2006), International tourism and the economic matrix, working paper series WP2006.6, School of Applied Economics, Victoria University, Melbourne.

Webster, A., Fletcher, J., Hardwick, P. and Morakabati Y. (2007), 'Tourism and empirical applications of international trade theory: a multi-country analysis', Tourism Economics, Vol 13, pp 657-674.

Webster, A., and Hardwick, P. (2005), 'International trade in financial services', The Service Industries Journal, Vol 25, pp 721-746.

Williams, S. (2009), Tourism geography, a new synthesis, London: Routledge. 
${ }^{\mathrm{i}}$ For example, in 2008, rich and emerging countries generated two thirds of total international tourism receipts and earned three quarters of this total by receiving 70\% of international tourist arrivals (UNWTO, 2010a, 2010b).

${ }^{\text {ii }}$ For each country, trade in tourism services has been studied so far on a multilateral basis by considering flows with all its partners together, defined as a single bloc. That is, only its exports to the rest of the world and its imports from the rest of the world have been analyzed.

iii To our knowledge, our paper is one of the first applications of Azhar and Elliott's (2006) method. For an application by these authors, see Azhar et al. (2008).

iv The two other methods had been suggested by Greenaway et al (1995), and by Fontagné and Freudenberg (1997). For a systematic comparison of the three approaches using real data, see Azhar et al (2008).

v The interpretation of this index is similar to the one for $G L$ index. If the sum of import and export unit values $\left(U V_{i, j, k}^{X}+U V_{i, j, k}^{M}\right)$ is viewed as total costs or quality, then index $P Q H_{i, j}^{k}$ gives the share of overlap between export unit value and import unit value in the total cost.

${ }^{\text {vi }}$ The data for Belgium and Luxembourg is combined into one entity and data for Ireland is not included.

${ }^{\text {vii }}$ For example, as indicated, Spain did not declare its tourism flows with the EU14. For this reason, when we study the pair France-Spain, we use only the data reported by France.

${ }^{\text {viii }}$ For example, in 2002, the United Kingdom estimated that its exports of tourism services to the Netherlands totaled 827 million dollars, while the Netherlands estimated their imports of tourism services from the United Kingdom at 1160 million dollars. This led us to remove certain pairs from the study because the differences between reports were too great for the data to be considered reliable: Austria/Belgium-Luxembourg, Austria/United Kingdom, France/Greece and France/Portugal.

ix As usual with dummies, the interpretation of these variables'coefficients directly depends on the choice of the reference variable. It is necessary to select as reference a country whose reported flows values seem the most reliable. Three criteria have to be fulfilled. First, the country must have declared its bilateral tourism flows for the whole period and with all other countries in the sample. Second, the average of the differences in its reported tourism trade flows with its partner countries must be as small as possible. Third, the differences between its reported flows and those of its partners must not be too scattered. Two countries fulfil these criteria satisfactorily: Finland for tourism exports and Portugal for tourism imports. We thus chose these two countries as references to interpret the coefficients.

${ }^{x}$ Assume that two countries, $A$ and $B$, exchange a total of $\$ 200$ of tourism services per year with each other. $A$ receives 18 tourists from $B$, and $B$ receives 20 tourists from $A$. Let us also assume that $A$ and $B$ have the same local price levels. If we define the export unit values of tourism services simply as the average spending per tourist, we find $\$ 11.11$ and $\$ 10$ for $A$ and $\mathrm{B}$ respectively. In this case, Azhar and Elliott' $\mathrm{PQH}$ index is equal to 0.94 . According to their " $85 \%$ cost share rule" $(0.85 \leq \mathrm{PQH} \leq 1.15)$, these tourism flows should be considered of similar quality (horizontal differentiation). But taking into account the tourists' length of stay can lead to the opposite conclusion. Let us assume that the tourists coming from $B$ spend on average ten days in country $A$ and that the tourists coming from $A$ spend two days on average in country $B$. The export unit value calculated as the average spending per tourist and per day is then respectively $\$ 1.11$ and $\$ 5$ for $A$ and $B$ respectively. In this case, $\mathrm{PQH}=0.36<0.85$ : according to Azhar and Elliot's criterion, the tourism services exported by $A$ to $B$ are of a lower quality than those exported by $B$ to $A$ (vertical differentiation). We would thus be in a situation of intra-tourism trade in vertically differentiated products.

${ }^{\mathrm{xi}}$ International tourism services data is the same as in the previous section (corrected OECD data). Nights spent by tourists according to their nationality are published by the World Tourism Organization. We chose the rubric "Overnight stays of non-resident tourists in all types of accommodation establishments, by country of residence" in UNWTO (2006).

xii Ireland could not be taken into account at the aggregated level as the number of reports concerning this country is extremely limited. However, we use the bilateral data for this country in the sample analysis.

xiii With an aggregated GL indicator falling between $50 \%$ and $66 \%$, we consider that intra-industry tourism trade is significant but not predominant.

xiv These figures concern a period that predates our own and are thus perhaps not directly comparable to our data. The study by Fontagné et al (1997) however is the only one, to our knowledge, which describes intra-industry intra-EU14 by industry.

${ }^{x v}$ To check the robustness of our results and their sensitivity to changes in the choice of the threshold, we then tested a large range of values for the thresholds of Azhar and Elliot's method (see below and table in the appendix). 